\title{
EFFECTS OF INTERACTION OF POPLAR-WHEAT INTERCROPPING SYSTEM ON SOIL QUALITY AND YIELD OF WHEAT (TRITICUM AESTIVUM L.)
}

\author{
SHWETA* \\ Department of Agronomy, CCSHAU, Hisar-125004, India
}

Keywords: Interaction, Poplar, Yield, Wheat, Intercropping, Soil quality

\begin{abstract}
The significantly higher wheat grain yield in open condition i.e. in control was recorded (4.33 t/ha) over to poplar intercropping. Under the poplar plantation, wheat yield significantly affected and paired row plantation $(18 \times 2 \times 2 \mathrm{~m}$ spacing) provides significantly higher grain yield and to $5 \times 4 \mathrm{~m}$ and $10 \times 2 \mathrm{~m}$ spacing.
\end{abstract}

Cultivated land is $82 \%$ of total geographic land of Haryana, so for increasing the productivity depends on intensive use of inputs. (Singh 2000). Day by day population is increasing and for fulfillment of food requirement use of high amount of chemicals and fertilizers, which cause dreadful conditions of soil quality. The most of soils having salinity and alkalinity problems and cause pressure on the food safety in future. the deforestation for development activities for human habitation and intensive agriculture resulted ecological imbalances. The climate change is also occurring and by this temperature and rainfall become changed, and productivity of all crops is affected. For proper use of land or diversifying land use systems there should be plantation of tree and intercropping of cereal and pulses with them to fulfill the requirement of the food, fodder and fuel-wood etc. Adoption of agroforestry system can insure the production on long term basis and play an important role in sustaining the natural resources.

Appropriate selection of crops with forestry tree for intercropping helps to increase productivity, improves soil fertility and promotes resource use efficiency and land sustainability (Dhyani et al. 2009, Antonio and Gama 2011). Agroforestry system based on poplar is more money-spinning than many of other crop rotations in northern part of India (Chauhan et al. 2015). Intercropping with short rotation tree species is the best option to meet the food and industrial raw requirement by maximum utilization of natural resources (Sarvade et al. 2014). Due to the fast growing, high price and less competition with intercrops, Populous sp. has been grown by the farmers in northern part of India. This improves the soil properties by addition of organic matter in the soil and provides employment to the people (Puri and Nair 2004, Singh and Sharma 2007l). Populus sp. is recognized as an important tree in agro-forestry system. This tree adds leaf litter in huge quantity which improve the soil status in term of organic carbon, available N, P, K and micronutrients and soil microbial population (Lodhiyal et al. 1995, Joshi et al. 1997). Populous sp. by escalation of above and below ground growth adds organic matter inputs and nutrient cycling, ameliorate availability of macro- and micronutrients. In this regard, the present investigation was undertaken to study the effect of poplar - wheat intercropping system on soil quality and yield of wheat under different spacing.

The study was carried out at forestry farm area of CCSHAU, Hisar, Haryana, India located at $75^{\circ} 46^{\prime}$ longitudes and $29^{\circ} 10^{\prime}$ latitudes and elevation of $215 \mathrm{~m}$ above mean sea level. Hisar is situated in the semi-arid region of north-western part of India. The soil of the experimental site

*Author for correspondence: <malik.shweta54@gmail.com>. 
was sandy loam in texture and slightly saline in reaction $(\mathrm{pH}$ 8.2) with medium in $\mathrm{OC}$, available $\mathrm{N}, \mathrm{P}$ and $\mathrm{K}$. The mean maximum temperatures during the hottest month (May) reached up to $45^{\circ} \mathrm{C}$ and mean minimum temperature during the coolest months (December and January) reached up to $0^{\circ} \mathrm{C}$. The average annual rainfall is $300-400 \mathrm{~mm}$, most of which is received during the period of June to September. The site received $21.15 \mathrm{~mm}$ rain fall during the wheat crop (November to April, 2014 - 2015). The study conducted on well established 8 year old poplar plantation at $5 \times 4$ $\mathrm{m}, 10 \times 2 \mathrm{~m}$, and $18 \times 2 \times 2 \mathrm{~m}$ (paired row) spacing. The sowing of wheat variety HD-2967 was done on 7 November, 2014 with the seed rate of $100 \mathrm{~kg} / \mathrm{ha}$. Recommended dose of fertilizer was applied of which half of nitrogen and full dose of $\mathrm{P}$ and $\mathrm{K}$ was applied at the time of sowing and rest dose of nitrogen at the time of CRI stage. Soil samples were collected randomly from 4 places at $0-15 \mathrm{~cm}$ top soil surface and mixed them properly and then half $\mathrm{kg}$ soil was taken for analysis with three replication. The soil analysis was done in two stages, before sowing and after harvest.

The wheat grain and straw yield was estimated under poplar tree and open condition with the help of $1 \times 1 \mathrm{M}$ quadrate and converted into $\mathrm{kg}$ per hectare. Soil $\mathrm{pH}$ was determined by using glass electrode $\mathrm{pH}$ meter, soil organic carbon by using modified Walkley and Blacks method and $\mathrm{N}$ was determined following Micro-Kjeldahl's method, $\mathrm{P}$ was estimated by spectrophotometry method and K was determined by Flame photometric method, respectively (Jackson 1973).

The significantly higher wheat grain yield in open condition i.e. in control was recorded (4.33 t/ha) over to poplar intercropping. Under the plantation wheat yield significantly affected and paired row plantation $(18 \times 2 \times 2 \mathrm{~m}$ spacing) provides significantly higher grain yield and to $5 \times 4$ $\mathrm{m}$ and $10 \times 2 \mathrm{~m}$ spacing. The grain yield of wheat under $5 \times 4$ and $10 \times 2 \mathrm{~m}$ spacing was at par to each other. The reduction in yield up to $85.48 \%$ under $5 \times 2 \mathrm{~m}$ spacing and $60.14 \%$ under paired row plantation. In straw yield, $13.18 \%$ reduced under paired row and $66.38 \%$ reduction was found under $5 \times 4 \mathrm{~m}$ plantation. The poplar crop inter-plantation modified the microclimate by reducing the social radiation, lowering the air temperature and enhancing the humidity. Various poplar inter-plantations have great impact on plant morphology, yield and crop quality.

With the increase of the age of poplar tree soil $\mathrm{pH}$ was decreased under all the conditions. Before sowing the crop the highest soil $\mathrm{pH}$ (8.1) was found in control condition and closely followed by paired row spacing $18 \times 2 \times 2 \mathrm{~m}$ (7.9). The soil $\mathrm{pH}$ after wheat harvest followed the same pattern and found maximum in control (7.9) and followed by paired row spacing (7.8) (Fig. $1 \mathrm{a}, \mathrm{b})$. The lower $\mathrm{pH}$ was found under field crop with poplar system than to sole wheat crop this might be due to accumulation of organic substances beneath the trees and release of weak organic acids during litter decomposition, The present finding correlates with the reported result of Uthappa et al. (2015).

Electrical conductivity of soil decreased after the cultivation of crop and reached up 0.08 under $5 \times 4 \mathrm{~m}$ spacing and 0.21 under sole wheat crop or control condition during the study period. Under sole wheat crop EC reduced to $28.57 \%$ from its initial value or before sowing the wheat crop (Fig. 2a, b). Wheat crop under poplar reduction in EC was more because of addition of leaf litter and organic substances which release organic acids. This finding agrees with the results reported by Gupta and Sharma (2009).

Soil organic carbon increased from its initial value under different spacing of poplar based agro forestry system and control (sole wheat crop) (Fig. 3). When poplar spacing was less, soil organic carbon was maximum (0.72) under $5 \times 4 \mathrm{~m}$ of spacing and control treatment have minimum soil organic carbon (0.48) before sowing of wheat crop.

The soil organic carbon in $5 \times 4 \mathrm{~m}, 10 \times 2 \mathrm{~m}, 18 \times 2 \times 2 \mathrm{~m}$ (paired row) spacing was higher by $54.17,45.83$ and $35.42 \%$, respectively over sole crop after harvesting of wheat crop during study. In agriculture crop residues lignified cells are less comparison to trees and tillage operation 


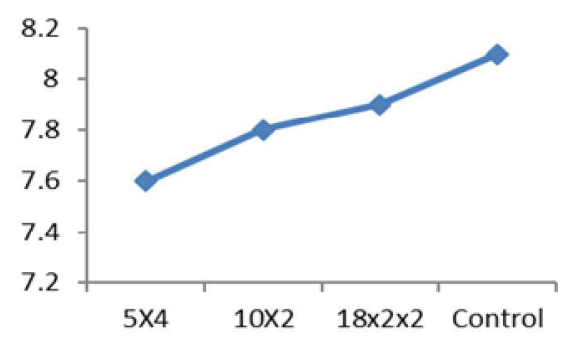

(a)

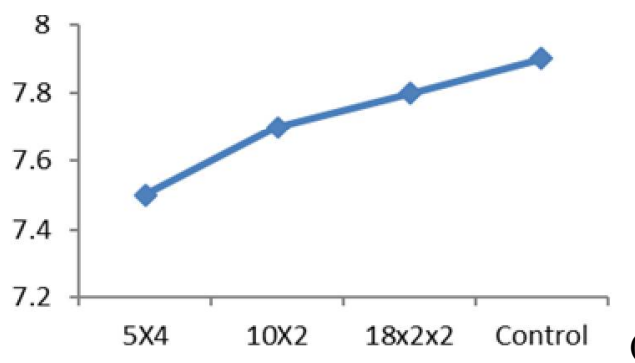

(b)

Fig. 1. pH of soil before sowing (a) and after harvest (b) of wheat..

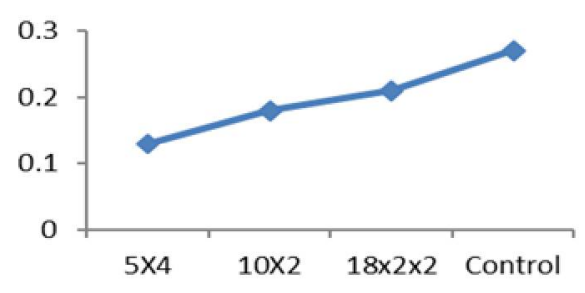

(a)

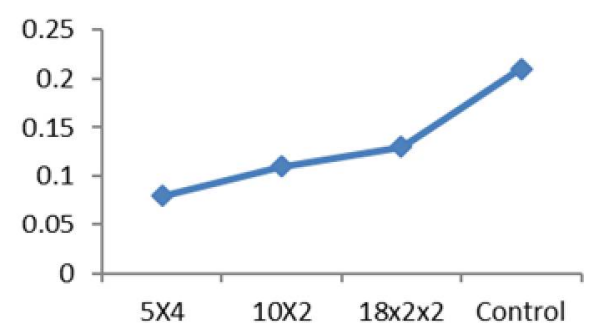

Fig. 2. Electrical conductivity before (a) and after (b) of wheat.

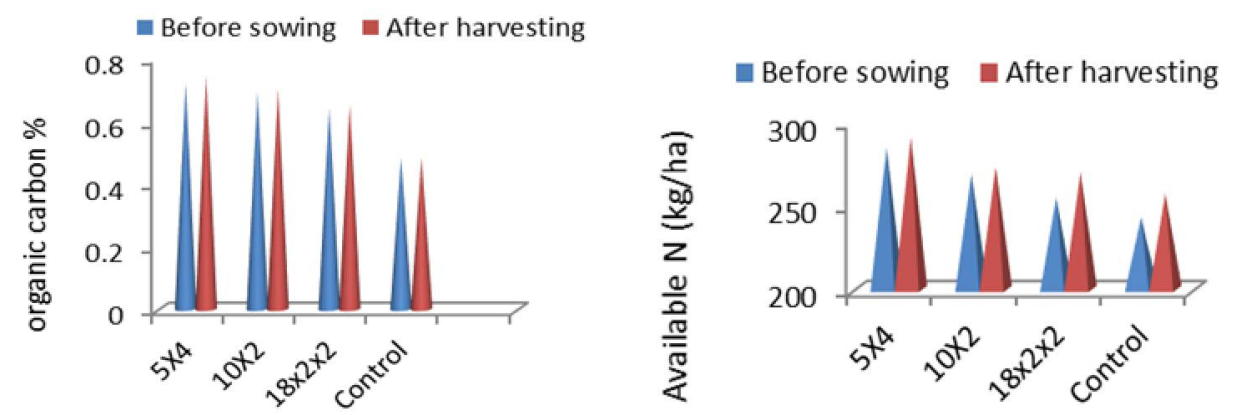

Fig. 3. Organic carbon and available $\mathrm{N}$ status of soil before and after harvest of wheat.
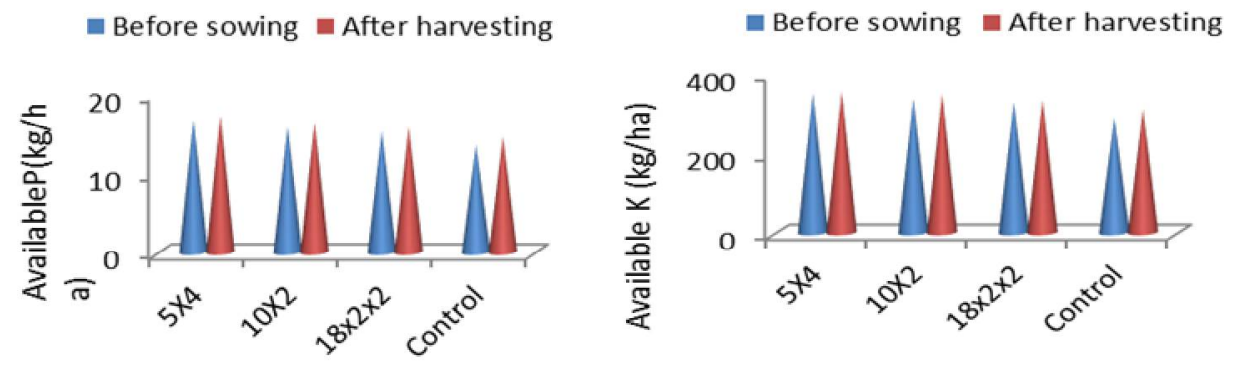

Fig. 4. Available $\mathrm{P}$ and $\mathrm{K}$ status of soil before and after harvest of wheat.

in the field cause full exposure to sun light and reduction in soil organic carbon. Sole cropping with continuous removal of nutrients from soil attributed less SOC. Agroforestry system could be ascribed to leaf fall, root biomass recycling, and root exudates and their reduced oxidation of 
organic matter under tree shade, which may be incorporated into the soil and its partial decomposition adds to the soil organic matter, also agree with the findings of Singh et al. (1989), Das et al. (2005) and Antonio and Gama-Rodrigues (2011).

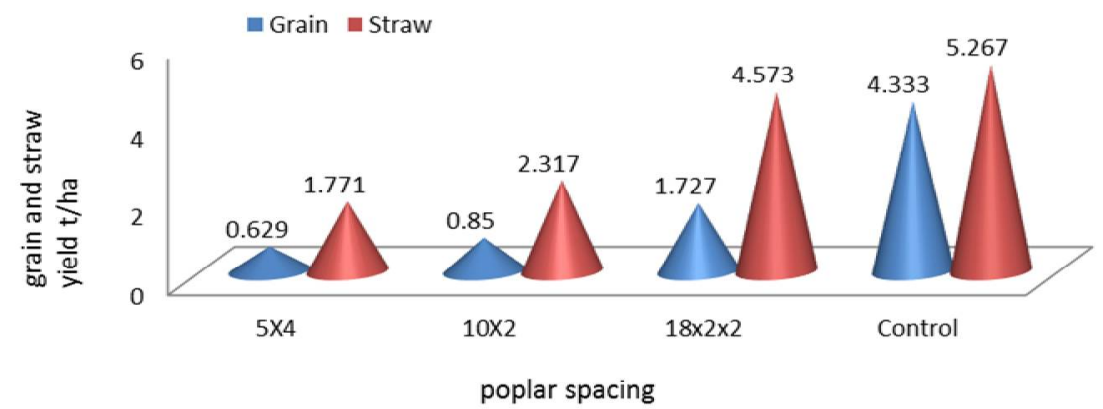

Fig. 5. wheat grain and straw yield under different poplar spacing,

The effect of different spacing of poplar-based agroforestry system and sole crop on available nitrogen was shown in Fig. 3b. In all the treatments available $\mathrm{N}$ increased from its initial value (before crop sowing). Availability of nitrogen to the crop is directly affected by organic carbon matter. Available $\mathrm{N}$ content was maximum $(284 \mathrm{~kg} / \mathrm{ha})$ under $5 \times 4 \mathrm{~m}$ spacing and the lowest was under control. The available $\mathrm{N}$ in $5 \times 4 \mathrm{~m}, 10 \times 2 \mathrm{~m}, 18 \times 2 \times 2 \mathrm{~m}$ (paired row) spacing was higher by $13.29,6.28$ and $4.96 \%$, respectively over sole crop after harvesting of wheat crop during the study. Similar trend was found in available $\mathrm{N}$ followed by available $\mathrm{P}$. Under sole crop soil available $\mathrm{P}$ was $14.5 \mathrm{~kg} / \mathrm{ha}$, while with poplar trees it ranged from 15.7 to $17.2 \mathrm{~kg} / \mathrm{ha}$. The available $\mathrm{P}(17.2 \mathrm{~kg} / \mathrm{ha})$ was highest under $5 \times 4 \mathrm{M}$ spacing of poplar, while it was lowest under sole crop (14.5 kg/ha) after harvesting of wheat crop. The higher nutrient status with less spacing or closer plantation of poplar might be due to accumulation of litter. The higher nutrient content in poplar wheat system over to wheat system may be attributed to litter fall from trees as well as addition of roots of trees and crops. Like as N, P and K also followed the similar pattern. The impact of intercropping with agroforestry trees on soil nutrient status in term of eminent OC, availability of NPK in top soil also reported by Mishra et al. (2010) and Rizvi et al. (2011) in wheat as intercrop with poplar.

It may be concluded that in poplar based agroforestry system $\mathrm{OC}$, available $\mathrm{N}, \mathrm{P}$ and $\mathrm{K}$ content in top soil improved. $5 \times 4$ and $10 \times 2 \mathrm{~m}$ spacing was suitable for increasing soil quality by addition of leaf litter. Highest grain yield was recorded under control, but one can get the additional wheat grain yield by taking the wheat as a intercrop with poplar.

\section{References}

Antonio, C and Gama-Rodrigues 2011. Soil organic matter, nutrient cycling and biological dinitrogenfixation in agroforestry systems. Agroforestry Systems 81: 191-193.

Chauhan SK, Saini KS, Saralch HS, Rani S and Verma A 2015. Wheat and barley crop performance under different sowing methods under poplar-based agroforestry system. Indian J. Ecology 42(2): 528-530.

Das DK and Chaturved, OP 2005. Structure and function of Populus deltoides agroforestry system in eastern India: 1. Dry matter dynamics. Agrofor. Syst. 65(3): 215-221.

Dhyani SK, Ajit and Handa AK 2009. Agroforestry potential and scope for development across agro-climatic zones in India. Indian J. Forestry 32: 181-190.

Gupta, M.K., Sharma, S.D. (2009), Effect of tree plantation on soil properties, profile morphology and productivity index: poplar in Yamunagar district of Haryana. Annals of Forestry 17 (1): 43-70. 
Jackson ML 1973. Soil chemical analysis. Prentice Hall PVT Ltd., India.

Joshi M, Bargali K and Bargali SS 1997. Changes in physico-chemical properties and metabolic activity of soil in poplar plantations replacing natural broad-leaved forests. J. Arid. Environ. 35: 161-169.

Lodhiyal LS, Singh RP and Singh SP 1995. Structure and function of an age series of poplar plantations in Central Himalaya. Dry matter dynamics. Ann. Bot. 76: 191-199.

Mishra A, Swamy SL, Bargali SS and Singh AK 2010. Tree growth, biomass and productivity of wheat under five promising clones of Populus deltoides. Int. J. Ecol. Environ. Sci. 36(2-3): 167-174.

Puri, S. and Nair, P.K.R. 2004. Agroforestry research for development in India: 25 years of experiences of a national program. Agrofor. Systems 61: 437-452.

Rizvi RH, Dhyani SK, Yadav RS and Singh R 2011. Biomass production and carbon stock of poplar agroforestry systems in Yamunagar and Saharanpur districts of northwest India. Curr. Sci. 100(5): 736-742.

Sarvade S, Mishra HS, Kaushal R, Chaturvedi S and Tewari S 2014. Wheat (Triticum aestivum L.) yield and soil properties as influenced by different agri-silviculture systems of terai region, northern India. International Journal of Bio-resourse and Stress Management 5(3): 350-355.

Singh B and Sharma KN 2007. Litter fall and nutrient return in poplar (Populous deltoids Bartr.) based agroforestry system in Punjab, India. Agrofor. System 70: 125-134.

Singh K, Chauhan HS, Rajput DK and Singh DV 1989. Report of a 60 month study on litter production, changes in soil chemical properties and productivity under poplar (Populus deltoides) and eucalypts (Eucalyptus hybrid) interplanted with aromatic grasses. Agrofor. Syst. 9: 37-45.

Singh RB 2000. Environmental consequences of agricultural development: A case study from the green revolution state of Haryana, India. Agric. Ecosyst. Environ. 82: 97-103.

Uthappa AR, Bana OPS, Kumar M and Kanwal M 2015. Soil physico-bio-chemical properties as influenced by varying tree densities in poplar (Populus deltoides Bartr. ex Marsh.) based agroforestry system. Indian J. Agrofor. 17(1): 81-90. 